\title{
Mandatory Solar Ordinance Benefits the Homeowner and the Community
}

\begin{abstract}
While society's energy consumption only tend to increase and traditional solutions for these needs have lasting environmental impacts, the capture and use of solar energy becomes vital. California has always been in the forefront of enviromental efforts through legislation and regulatory efforts. In this article, an abstract of his senior project, Darya Oreizi discusses the potential impacts of mandatory solar ordinances.
\end{abstract}

C alifornia has always been on the forefront of adaptive regulations to combat its economical and environmental adversities. Specifically, electricity has increased in price over the years while maintaining the release of harmful air pollution and greenhouse gases.

Since 2000, residential electricity rates have increased over $65 \%$, as reported by the Energy Information Administration. Essentially, every year rates increases $6 \%$. Specifically, baseline rates have increased from $\$ 8.95$ per kWh (kilowatt-hour) in 2008 to $\$ 12.10$ per $\mathrm{kWh}$ in 2012 . This is due to a number of factors:

- Increasing demand

- Increasing capital costs for new power plants

- Increasing infrastructure and repair costs

- Increasing fossil fuel costs

Despite California enacting the Renewable Portfolio Standard (RPS) in 2007, a regulation requiring all utility companies to produce at least $30 \%$ of electricity from renewable sources by 2020 , fossil fuels have been the choice fuel for electricity generation. Burning fossil fuels has numerous economical, public health, and environmental problems. According to the Environmental Protection Agency (EPA), electricity generation accounted for $31 \%$ of total greenhouse gas emissions (GHG) in the United States in 2013.

As noted in a research by the Center For Disease Control, public health costs from GHGs were estimated to have cost $\$ 6.5$ billion in 2008. Furthermore, GHG emissions are linked to climate change, which carries numerous negative effects, such as increase heat wave frequency and longer drought spells. As

Note: The author based this article on his senior project, available at $<$ http://digitalcommons.calpoly.edu/crpsp/> stated by the EPA, "Over the past three decades, nearly 8,000 Americans were reported to have died as a direct result of heat-related illnesses such as heat stroke".

Converting sunlight in electricity is a minimal carbon emitting process. The Intergovernmental Panel on Climate Change found the counterpart, fossil fuels, emit anywhere from 469 to 1,001 grams of CO2e (Carbon Dioxide equivalent) per kWh whereas solar only emits 46 grams of CO2e per kWh. As reported by the Rocky Mountain Institute, electricity generation costs the United States $\$ 100$ billion a year.

Fossil fuel power plants also release vast amounts of air pollutants. These power plants emit pollutants such as nitrous oxides and sulfur oxides. For example, a natural gas power plant releases 1.7 pounds of nitrous oxides per MWh (megawatthour). These pollutants negatively impact the health of living species in the surrounding area. Health impacts from inhaling too much pollution causes respiratory and vision problems. Pollution from solar PV from the manufacture process is negligible.

Furthermore, fossil fuel power plants consume vast amounts of water to produce electricity. A recent report entitled, Burning Our Rivers, found for every MWh generated, fossil fuels consume 172-692 gallons depending on which fossil fuel (i.e. natural gas, coal). On the other hand, solar only consumes 2 gallons per MWh (for manufacturing and cleaning purposes). Less water for power plants equates to more water for agriculture and community use.

Within the past decade, homeowners and developers have taken this problem into their own hands. Since the past decade, the use of residential solar photovoltaic (PV) systems has increased dramatically. With much help from the California Solar Initiative, a state-run tax deduction program, residential solar has increased over 1,800 MW in 10 years just from the 
program alone. On top of state incentives, homeowners and developers are able take advantage of the Federal solar Investment Tax Credit (ITC), which offers a 30\% tax credit off the total cost of the solar PV system. The ITC was renewed in 2008, but will expire at the end of 2016. The solar industry has also boomed due to the increase in demand along with the refining of technologies reflected in the decrease of cost. The Solar Energies Industries Association observed that just between 2011 and 2013, the total cost of a system decreased by $60 \%$.

Numerous studies prove the cost effectiveness of residential solar. A research of over 45,000 homes in California, conducted by Clean Power Research, found the lifetime savings (20 years) of a solar PV system accounted to over $\$ 34,000$. Another study by Energy Informative found similar results. By using national electricity consumption, electricity rate, and PV system cost averages, the study found homeowners save over $\$ 21,000$ over the life of the panels. In addition, a study by the Lawrence Berkeley National Laboratory found homes with solar increase property values from $\$ 4,600$ to $\$ 26,000$ depending on the size of the system.

The combination of state and federal incentives, decreasing costs of the technologies, savings in monthly electricity costs, and the real-estate appreciation are factors that increasingly encourage residential solar systems. On the other side, cities that adopt mandatory solar ordinances will not only save energy costs and increase home values for homeowners, but also benefit the community in multiple ways, such as reducing greenhouse gases, air pollution, and water consumption. However, the solar industry has only made a slight dent in the fossil fuel empire. Cities have to take the lead to really make a difference in how communities acquire energy for the sake of the economy, public health, and the natural environment.

The California Global Warming Solutions Act of 2006, or AB 32, and Climate Action Plans (CAP) provide cities opportunities to change how communities acquire energy with legislature as justification. $A B 32$ requires California to reduce GHG emissions to 1990 levels by 2020. Switching away from fossil fuels to solar for electricity generation easily qualifies as a solution to the state GHG reduction mandate. In addition, CAP layout exactly how cities will reduce GHGs. For example, the City of Piedmont includes solar PV systems in its CAP as a method to decrease GHG.

California cities can also advance the move towards a more energy efficient way-of-life through more specific legislation affecting residential development. Lancaster and Sebastopol, for example, have already taken the initiative, and have passed mandated solar ordinances for new residential development in 2014. Since adoption, both cities have yet to see any resistance to the ordinance, possibly because homeowners experience significant energy savings as well as community pride for their environmental efforts. Lancaster Planner, Chuen $\mathrm{Ng}$, explained

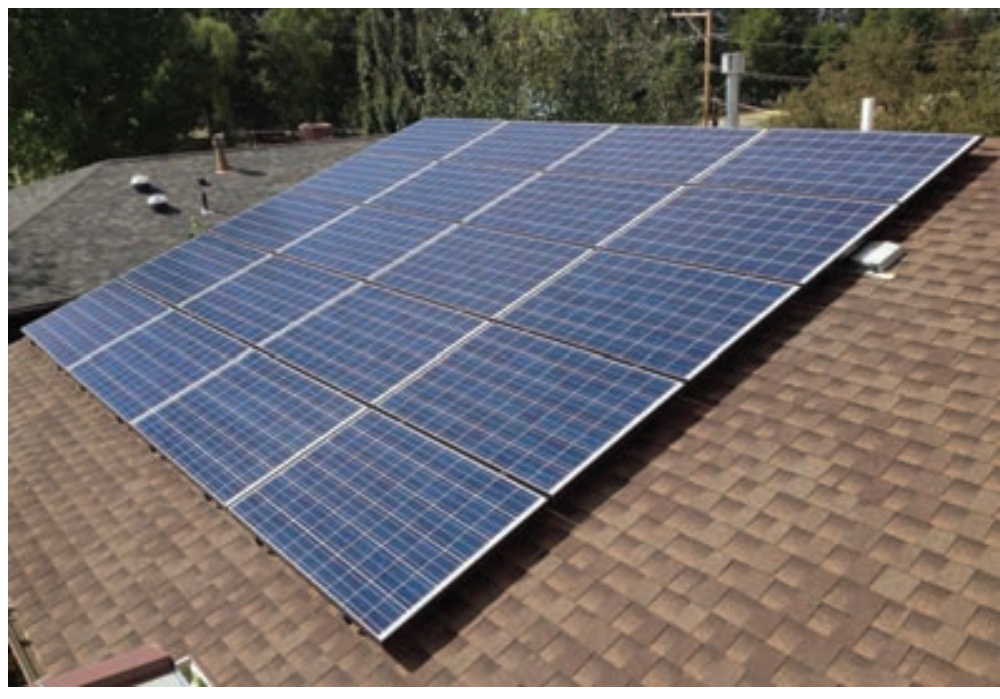

Figures 1 and 2: Detail of solar panels on a roof (top) and a totally integrated architectural solution (below). Photos courtesy of Sunrun, San Luis Obispo.

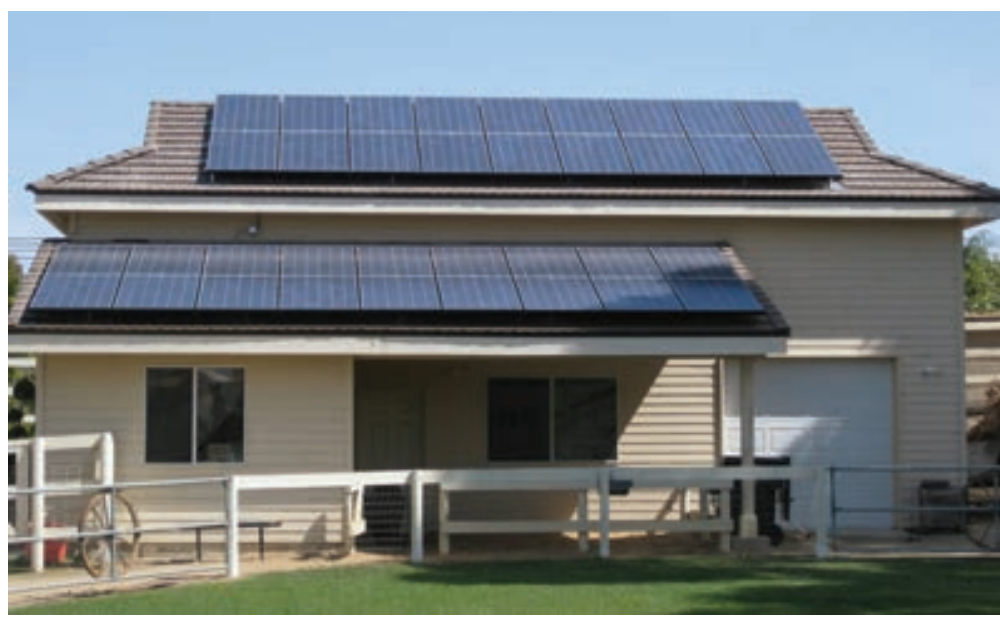

how Lancaster and other California cities could be successful to implement such an ordinance. Ng stated, "Most importantly, you need support from stakeholders". As Sebastopol Building Official, Glenn Schainblatt stated, "[the mandatory solar ordinance] really wasn't that hard to do".

City budgets can impede innovated regulations or measures that would benefit the community. However, both Lancaster's and Sebastopol's solar ordinances cost little to zero dollars to the city. Lancaster adds the entire tab for the solar PV system to the homeowner. This includes permits, installation, and hardware costs. Though this adds $\$ 20,000-\$ 30,000$ (preincentive) costs to the new house, the initial investment is found to be popular due to the significant energy savings and quick ROI (return on investment) as reported by Lancaster and Sebastopol city staff. 
The devastating effects of the California Energy Crisis of 2001 should not be forgotten. Cities have the ability to avert increasing residential energy expenditures and excessive GHG emissions. Mandatory solar ordinances for new residential development would benefit not just the homeowner, but also the community. These ordinances not only benefit the community's economics, public health, and the local environment, but also qualify for several state legislatures like $A B$ 32. Altogether, mandatory solar ordinances are necessary for healthy and sustainable cities.

\section{References}

California Solar Initiative (CSI). 2015. Go Solar California. $<$ http://www.gosolarcalifornia.ca.gov/about/csi.php > (access $4 / 11 / 2015)$

Environmental Protection Agency (EPA). 2015. Climate Change. <http://www.epa.gov/climatechange> (access 4/15/2015).

State of California. 2015. Executive Order B-29-15. <http://gov. ca.gov/docs/4.1.15_Executive_Order.pdf $>$ (access 4/11/2015)

Hoen, Ben; Wiser, Ryan and Capper, Peter. 2011. An Analysis of the Effects of Residential Photovoltaic Energy Systems on Home Sales Prices in California. A report by the Ernest Orlando Lawrence Berkeley National Laboratory. <http://emp.lbl.gov/ sites/all/files/lbnl-4476e.pdf $>$ (access 4/17/2015)

U.S. Energy Information Administration. 2015. Electricity Data Browser. <http://www.eia.gov/electricity/data/browser> (access 4/19/2015.

City of Lancaster. 2015. Lancaster Building Code: Chapter 15. Building Code. <https://www.municode.com/library/ca/lancaster/codes/code_of_ordinances > (access 4/17/2015).

Nagourney, Adam. 2015. California Imposes First Mandatory Water Restrictions to Deal With Drought." The New York Times April 2, 2015. <http://www.nytimes.com/2015/04/02/us/ california-imposes-first-ever-water-restrictions-to-deal-withdrought.html> (access 5/5/2015).

Solar Energy Industries Association (SEIA). 2015. Solar Industry Facts and Figures. <http://www.seia.org/research-resources/ solar-industry-data> (access 5/7/2015)

Wilson, Wendy; Leipzig, Travis \& Griffiths-Sattenspiel, Bevan. 2012. Burning Our Rivers - The Water Footprint of Electricity. Portland, OR: River Network.

\section{Phone Interviews}

$\mathrm{Ng}$, Chuen. Planner for the City of Lancaster. 4/9/2015. Schainblatt, Glenn. Planner for the City of Sebastopol. $2 / 24 / 2015$ 